\title{
BIBECHANA
}

A Multidisciplinary Journal of Science, Technology and Mathematics

\section{A Convenient route for the synthesis of antimicrobial 1 , 3, 4- thiadiazole derivatives}

\author{
A. D. Mishra \\ Dept. of Chemistry, Tribhuvan University, P. N. Campus, Pokhara \\ Ph. No.: 061-540414 / Mob, No.: 9846027853 \\ e-mail: mishraad05@hotmail.com \\ Article history: Received 18 May, 2011; Accepted 17 June, 2011
}

\begin{abstract}
Thiosemicarbazide of 6-chloro-2- aminobenzothiazole on cyclization with different aromatic carboxylic acids in Phosphorus oxychloride provided the corresponding 2-aryl-5-(6'-chloro-1',3'benzothiazole-2-yl-amino)-1,3,4-thiadiazoles 4a-j. The compounds are characterized by elemental analysis, IR and ${ }^{1} \mathrm{H}$ NMR spectral data. All the compounds are evaluated in vitro for their antimicrobial activities against several fungal and bacterial strains and showed significant activities.
\end{abstract}

Keywords: Aminobenzothiazole; 1, 3, 4- thiadiazole; antimicrobial; cyclization

\section{Introduction}

Benzothiozoles are bicyclic ring systems with diverse chemical reactivity and broad spectrum of biological activities such as antimicrobial[1,2], antitumor[3,4], anti-inflammatory[5,6]and antilieshmanial[7,8], etc. Several 1, 3, 4- thiadiazole derivatives are also known to exhibit diverse biological properties like antimicrobial $[9,10]$, antitubercular $[11,12]$, anti-inflammatory[13] and anticonvulsant[14]. The synthesis and biological activities of a few benzothiozole derivatives linked with 1,3,4-thiadiazole systems is reported here owing to their pharmaceutical importance.

The reaction sequence leading to the formation of the desired heterocyclic compounds are outlined in scheme 1.The 6-chloro-1,3-benzothiazol-2-yl-thiosemicarbazide 2 was prepared by the reaction of 6-chloro-2-aminobenzothiazole 1 with $\mathrm{CS}_{2}$ and hydrazine in the presence of ethanol. Several 2-aryl-5-(6'-chloro-1,'3'-benzothiazol-2-yl-amino)- 1, 3, 4- thiadiazoles 4a-j were synthesized by the reaction of 6-chloro-1,3-benzothiazol-2-yl-thiosemicarbazide 2 with various substituted aromatic carboxylic acids 3a-j in the presence of phosphorous oxychloride.

\section{Material and Methods}

Melting points were measured in open capillary tubes and are uncorrected. IR spectra were recorded on a Nicolet, 5PC FT-IR spectrometer in $\mathrm{KBr}$ pelletes and ${ }^{1} \mathrm{H}$ NMR spectra on the bruker DRX-300 FT NMR spectrometer using TMS as internal reference.Chemical shifts are observed with DMSO- $\mathrm{d}^{6}$ solvent in $\mathrm{ppm}$. The purity of the compounds was checked on silica gel 
G plates using iodine vapor as visualizing agents. Ofloxacin was used as standard dug for antibacterial activity ketoconazole as standard drug for antifungal activity $[15,16]$.

The precursor 6-chloro-2- aminobenzothiazole 1 was synthesized by the already reported procedure [17].

Scheme 1<smiles>NNC(=S)Nc1nc2ccc(Cl)cc2s1</smiles>

(1)<smiles>[R]c1nnc(Nc2nc3ccc(Cl)cc3s2)s1</smiles>

$(4 a-j)$

$\mathrm{R}=\mathrm{a}$. Phenyl $\quad$ b. 4-Chlorophenyl $\quad$ c. 2,4-Dichlorophenyl

$\begin{array}{lll}\text { d. 4-Nitrophenyl e. 2-Aminophenyl f. 2,4-Dichlorophenoxymethyl } & \text { e-A }\end{array}$

g. 2-Naphthylmethyl h. 4-methoxyphenyl i. 2-Acetoxyphenyl

j. 3-Pyridyl

\subsection{General Procedure for the Synthesis of 6-Chloro-1,3- benzothiazol-2-yl- thiosemicarbazide (2)}

The 6-chloro-2- aminobenzothiazole 1 (0.01 mole) was dissolved in ethanol $(90 \%, 50 \mathrm{ml})$ and then $\mathrm{CS}_{2}(20 \mathrm{ml})$ was added slowly within 10 minutes with constant shaking. The resulted solution was then allowed to stand for $1.0 \mathrm{hr}$. Then $20 \mathrm{ml}$ of $50 \%$ hydrazine solution was added to it. The reaction mixture was warmed slowly for $1.30 \mathrm{hr}$ then filtered, washed with cold water and dried. The solid thus obtained was purified by recrystallization from methanol.

\subsection{General Procedure for the Synthesis of 2-Aryl-5-(6'-chloro-1', 3'- benzothiazol-2-yl- amino)- $\quad$ 1,3,4-thiadiazoles (4a-j)}

A mixture of 6-chloro-1,3- benzothiazol-2-yl- thiosemicarbazide 2 (0.01 mole), an aromatic acid $3 a-j(0.01 \mathrm{~mole})$ and phosphorous oxychloride $(25 \mathrm{ml})$ was refluxed for $3 \mathrm{hr}$. After cooling to room temperature the reaction mixture was slowly poured over crushed ice and kept for $1 \mathrm{hr}$. The solid thus separated was filtered, washed with cold water, dried and purified by recrystallization from methanol.

\section{Results and Discussion}

All the synthesized thiadiazole derivatives $4 \mathrm{a}-\mathrm{j}$ are confirmed by different spectral analysis (table 2). These compounds have given similar IR and ${ }^{1} H$ NMR signals for main moiety with variations for substitutions. The characteristic observations for the substitutions have further supported the formation of mentioned products $\mathbf{4 a - j}$. The IR spectrum of the typical compound $\mathbf{4 i}$ showed absorption peak at $1710 \mathrm{~cm}^{-1}$ due to the stretching of $\mathrm{C}=0$. The $\mathrm{N}-\mathrm{H}$ stretching vibration appeared at $3436 \mathrm{~cm}^{-1}$. The absorption at $795 \mathrm{~cm}^{-1}$ was obtained due to $\mathrm{C}-\mathrm{Cl}$ stretching vibration. The ${ }^{1} \mathrm{H}$ 
NMR spectra of this compound displayed on singlet at $\delta 2.13$ showing the presence of $\mathrm{OCCH}_{3}$ protons of acetyl group. A broad singlet appeared at $\delta 12.36$ showing the presence of $\mathrm{NH}$ proton. The seven aromatic protons of benzothiozole and phenyl ring were observed as a multiplet at $\delta$ 7.5-8.0.

Table 1: Physical characterization data of compounds (4a-j)

\begin{tabular}{|c|c|c|c|}
\hline Comp.no & $R$ & Yield (\%) & m.p. $\left({ }^{\circ} \mathrm{C}\right)$ \\
\hline $4 a$ & Phenyl & 65 & 225 \\
\hline $4 b$ & 4-Chlorophenyl & 61 & 270 \\
\hline $4 \mathrm{c}$ & 2,4-dichlorophenyl & 67 & 283 \\
\hline $4 d$ & 4-Nitrophenyl & 72 & 285 \\
\hline $4 e$ & 2-Aminophenyl & 66 & 227 \\
\hline $4 f$ & 2,4-dichlorophenoxymethyl & 58 & 215 \\
\hline $4 \mathrm{~g}$ & 2-Napthylmethyl & 73 & 165 \\
\hline $4 \mathrm{~h}$ & 2-Methoxyphenyl & 61 & 201 \\
\hline $4 \mathrm{i}$ & 2-Acetoxyphenyl & 60 & 272 \\
\hline $4 \mathrm{j}$ & 3-Pyridyl & 55 & 242 \\
\hline
\end{tabular}

\section{Biological Evaluation}

All the compounds have been screened for both antibacterial and antifungal activities using cupplate agar diffusion method by measuring the inhibition zone in $\mathrm{mm}$. Ofloxacin $(50 \mu \mathrm{g} / \mathrm{ml})$ was used as a standard drug for antibacterial activity and ketoconazole $(50 \mu \mathrm{g} / \mathrm{ml})$ as a standard drug for antifungal activity. The compounds $\mathbf{4 a - j}$ were screened for antibacterial activity against $\mathrm{E}$. coli, $S$. aureus and $P$. aerugenosa in nutrient agar medium and for antifungal activity against $A$. niger and C. albicans in sabouraud's dextrose agar medium. These sterilized agar media were poured into petri-dishes and allowed to solidify. On the surface of media microbial suspensions were spreaded with the help of sterilized triangular loop. A presterilized stainless steel cylinder of $8 \mathrm{~mm}$ diameter was used to bore cavities. All synthesized compounds $(50 \mu \mathrm{g} / \mathrm{ml})$ were placed serially in the cavities with the help of micropipette and allowed to diffuse for $1.00 \mathrm{hr}$. DMF was used as a solvent for all the compounds and as a control. These plates were incubated at $37^{\circ} \mathrm{C}$ for $36 \mathrm{hr}$. and $28^{\circ} \mathrm{C}$ for $48 \mathrm{hr}$, for antibacterial and antifungal activities respectively. The zone of inhibition observed around the cups after respective incubation was measured and percentage inhibition of 
the compounds was calculated (tables $3 \& 4$ ). The thiadiazole derivative $4 \mathbf{i}$ having acetoxyphenyl group showed potent activity against $\mathrm{S}$. aureus(92\%), wereas compound $\mathbf{4 g}$ having 2nepthylmethyl group showed maximum inhibition against E. coli(95\%), when compared to standard drug ofloxacin. The compound 4c having 2,4-dichlorophenyl group also showed significant antibacterial activity $(85,87$ and $82 \%)$ against S. aureus, E. coli, and P. aerugenosa respectively. Rest of the compounds showed moderate to good antibacterial activity.

Table 2: Spectral data of the compounds $(4 a-j)$

\begin{tabular}{|c|c|c|}
\hline Comp.no. & $\mathrm{IR}, \mathrm{v}\left(\mathrm{cm}^{-1}\right)$ & ${ }^{1} \mathrm{H}$ NMR, $\delta$ (ppm) \\
\hline $4 a$ & $\begin{array}{l}3360(\mathrm{~N}-\mathrm{H}) \\
3030(\mathrm{C}-\mathrm{H}) \\
750(\mathrm{C}-\mathrm{Cl})\end{array}$ & $\begin{array}{c}\text { 7.35-7.8(m,8H,ArH }) \\
8.27(\mathrm{~S}, 1 \mathrm{H}, \mathrm{NH})\end{array}$ \\
\hline $4 b$ & $\begin{array}{l}3369(\mathrm{~N}-\mathrm{H}) \\
3032(\mathrm{C}-\mathrm{H}) \\
755(\mathrm{C}-\mathrm{Cl})\end{array}$ & $\begin{array}{c}\text { 7.30-7.96(m,7H,ArH }) \\
10.48(\mathrm{~S}, 1 \mathrm{H}, \mathrm{NH})\end{array}$ \\
\hline $4 \mathrm{c}$ & $\begin{array}{l}3386(\mathrm{~N}-\mathrm{H}) \\
3060(\mathrm{C}-\mathrm{H}) \\
765(\mathrm{C}-\mathrm{Cl})\end{array}$ & $\begin{array}{c}\text { 7.34-7.62(m,6H,ArH }) \\
10.50(\mathrm{~S}, 1 \mathrm{H}, \mathrm{NH})\end{array}$ \\
\hline $4 d$ & $\begin{array}{l}3366(\mathrm{~N}-\mathrm{H}) \\
3033(\mathrm{C}-\mathrm{H}) \\
752(\mathrm{C}-\mathrm{Cl})\end{array}$ & $\begin{array}{c}\text { 7.37-8.38(m,7H,ArH }) \\
13.25(\mathrm{~S}, 1 \mathrm{H}, \mathrm{NH})\end{array}$ \\
\hline $4 e$ & $\begin{array}{l}3411(\mathrm{~N}-\mathrm{H}) \\
3033(\mathrm{C}-\mathrm{H}) \\
752(\mathrm{C}-\mathrm{Cl})\end{array}$ & $\begin{array}{c}\left.\text { 4.5(S,2H, } \mathrm{NH}_{2}\right) \\
\text { 7.08-7.86(m,7H,ArH }) \\
12.56(\mathrm{~S}, 1 \mathrm{H}, \mathrm{NH})\end{array}$ \\
\hline $4 f$ & $\begin{array}{l}3408(\mathrm{~N}-\mathrm{H}) \\
3028(\mathrm{C}-\mathrm{H}) \\
750(\mathrm{C}-\mathrm{Cl})\end{array}$ & $\begin{array}{c}4.97\left(\mathrm{~S}, 2 \mathrm{H}, \mathrm{CH}_{2} \mathrm{O}\right) \\
7.06-7.89(\mathrm{~m}, 6 \mathrm{H}, \mathrm{ArH}) \\
12.59(\mathrm{~S}, 1 \mathrm{H}, \mathrm{NH})\end{array}$ \\
\hline $4 g$ & $\begin{array}{l}3402(\mathrm{~N}-\mathrm{H}) \\
3021(\mathrm{C}-\mathrm{H}) \\
752(\mathrm{C}-\mathrm{Cl})\end{array}$ & $\begin{array}{c}3.27\left(\mathrm{~S}, 2 \mathrm{H}, \mathrm{CH}_{2}\right) \\
7.50-7.87(\mathrm{~m}, 10 \mathrm{H}, \mathrm{ArH}) \\
12.34(\mathrm{~S}, 1 \mathrm{H}, \mathrm{NH}) \\
\end{array}$ \\
\hline $4 \mathrm{~h}$ & $\begin{array}{l}3399(\mathrm{~N}-\mathrm{H}) \\
3032(\mathrm{C}-\mathrm{H}) \\
752(\mathrm{C}-\mathrm{Cl})\end{array}$ & $\begin{array}{c}3.86\left(\mathrm{~S}, 3 \mathrm{H}, \mathrm{OCH}_{3}\right) \\
\text { 7.05-7.86(m,7H,ArH }) \\
12.56(\mathrm{~S}, 1 \mathrm{H}, \mathrm{NH})\end{array}$ \\
\hline $4 i$ & $\begin{array}{c}3436(\mathrm{~N}-\mathrm{H}) \\
3038(\mathrm{C}-\mathrm{H}) \\
1710(\mathrm{C}=\mathrm{O}) \\
795(\mathrm{C}-\mathrm{Cl})\end{array}$ & $\begin{array}{c}2.13\left(\mathrm{~S}, 3 \mathrm{H}, \mathrm{OCH}_{3}\right) \\
7.5-8.0(\mathrm{~m}, 7 \mathrm{H}, \mathrm{ArH}) \\
12.36(\mathrm{~S}, 1 \mathrm{H}, \mathrm{NH})\end{array}$ \\
\hline $4 j$ & $\begin{array}{l}3421(\mathrm{~N}-\mathrm{H}) \\
3036(\mathrm{C}-\mathrm{H}) \\
745(\mathrm{C}-\mathrm{Cl})\end{array}$ & $\begin{array}{c}\text { 7.05-7.89(m,7H,ArH }) \\
13.0(\mathrm{~S}, 1 \mathrm{H}, \mathrm{NH})\end{array}$ \\
\hline
\end{tabular}


Table 3: Antibacterial activity of 1, 3, 4-thiadiazole derivatives (4a-j)

\begin{tabular}{|c|c|c|c|c|c|c|}
\hline \multirow[t]{2}{*}{ Comp. } & \multicolumn{2}{|c|}{ Staphylococcus aureus } & \multicolumn{2}{|c|}{ Escherichia coli } & \multicolumn{2}{|c|}{$\begin{array}{c}\text { Pseudomonas } \\
\text { aerugenosa }\end{array}$} \\
\hline & $\begin{array}{c}\text { Zone of } \\
\text { inhibition } \\
\text { (mm) }\end{array}$ & $\begin{array}{c}\% \\
\text { inhibition }\end{array}$ & $\begin{array}{l}\text { Zone of } \\
\text { inhibition } \\
\text { (mm) }\end{array}$ & $\begin{array}{c}\% \\
\text { inhibition }\end{array}$ & $\begin{array}{c}\text { Zone of } \\
\text { inhibition } \\
(\mathrm{mm})\end{array}$ & $\begin{array}{c}\% \\
\text { inhibition }\end{array}$ \\
\hline $4 a$ & 10 & 65 & 9 & 63 & 13 & 77 \\
\hline $4 b$ & 12 & 80 & 10 & 69 & 12 & 70 \\
\hline $4 \mathrm{c}$ & 15 & 85 & 16 & 87 & 14 & 82 \\
\hline $4 d$ & 11 & 76 & 14 & 85 & 12 & 71 \\
\hline $4 e$ & 11 & 80 & 13 & 71 & 11 & 74 \\
\hline $4 f$ & 14 & 82 & 12 & 65 & 13 & 76 \\
\hline $4 g$ & 13 & 76 & 16 & 95 & 13 & 81 \\
\hline $4 \mathrm{~h}$ & 10 & 78 & 12 & 75 & 12 & 70 \\
\hline $4 \mathrm{i}$ & 16 & 92 & 13 & 72 & 14 & 83 \\
\hline $4 j$ & 12 & 80 & 11 & 69 & 13 & 79 \\
\hline
\end{tabular}

Table 4: Antifungal activity of 1, 3, 4- thiadiazole derivatives (4a-j)

\begin{tabular}{|c|c|c|c|c|}
\hline \multirow[b]{2}{*}{ Comp. } & \multicolumn{2}{|c|}{ Aspergillus niger } & \multicolumn{2}{|c|}{ Candida albicans } \\
\hline & $\begin{array}{l}\text { Zone of inhibition } \\
(\mathrm{mm})\end{array}$ & $\%$ inhibition & $\begin{array}{l}\text { Zone of inhibition } \\
(\mathrm{mm})\end{array}$ & $\%$ inhibition \\
\hline $4 a$ & 20 & 62 & 12 & 66 \\
\hline $4 \mathrm{~b}$ & 14 & 55 & 11 & 58 \\
\hline $4 \mathrm{c}$ & 13 & 47 & 13 & 62 \\
\hline $4 d$ & 11 & 45 & 11 & 61 \\
\hline $4 \mathrm{e}$ & 25 & 87 & 15 & 78 \\
\hline $4 f$ & 23 & 82 & 16 & 83 \\
\hline $4 \mathrm{~g}$ & 16 & 56 & 14 & 67 \\
\hline $4 \mathrm{~h}$ & 12 & 46 & 13 & 69 \\
\hline $4 i$ & 13 & 48 & 12 & 63 \\
\hline $4 j$ & 15 & 52 & 14 & 71 \\
\hline
\end{tabular}


The results of antifungal activity of the test compounds were quite different from their antibacterial activity. The 1,3,4- thiadiazole derivative $4 \mathrm{e}$ having 2-aminophenyl group showed maximum inhibition(87\%) against $A$. niger whereas $4 \mathrm{f}$ having 2,4-dichlorophenoxymethyl groups showed maximum inhibition (83\%) against C. albicans. Furthermore 1, 3, 4- thiadiazole dericatives $4 \mathbf{e}$ showed $78 \%$ inhibition against C. albicans. Whereas 4 f showed $82 \%$ inhibition against A. niger. Rest of the thiadiazole derivatives showed moderate to good antifungal activity as compared to the reference drug ketoconazole. Thus it is concluded from the screening results that 1,3,4thiadiazole derivatives $\mathbf{4 a - j}$ have been proved to be more effective against all the tested microorganisms at a concentration of $50 \mu \mathrm{g} / \mathrm{ml}$.

\section{Conclusion}

The reaction of 6-Chloro-2- aminobenzothiazole 1 with hydrazine and carbon disulphide in alcoholic medium yielded corresponding thiosemicarbazide 2 in excellent yield of $82 \%$ within $1 \mathrm{hr}$. Thus obtained thiosemicarbazide produced various 1,3,4-thiadiazoles $\mathbf{4 a - j}$, through cyclization upon reaction with carboxylic acids 3a-j in presence of phosphorous oxychloride in $75 \%$ yield within $3 \mathrm{hr}$. All the synthesized thiadiazoles $\mathbf{4 a - j}$, showed excellent to moderate antifungal and antibacterial activities, which has proved the thiadiazoles $4 a-j$ as pharmaceutically valuable heterocycles. This synthetic method is proved to be simple, easier to workup and environment friendly tool in pharmaceutical chemistry.

\section{Acknowledgements}

The auther is thankful to the Research Committee, Department of Chemistry and Department of Microbiology, Tribhuvan University,P. N. Campus, for providing miniresearch grant and available laboratory facilities regarding synthesis and microbial activities of the compounds. Thanks are due to the Instrumental Laboratory, Department of Chemistry, University of Delhi, for assisting in spectral analysis of all the synthesized compounds.

\section{References}

[1] I. Yildiz-Oren, I. Yalein and N. Ucartruk, Eur J Med Chem. 39 (2004) 291.

[2] F. Delmas, A. Avellaneda, C.D. Gioegia, E.D. Robin Clereq, and J.P. Galy, Eur J Med Chem. $39(2004) 685$.

[3] N.K. Wadoker and M.A. Dhiman, Indian J Chem. 40B (2001) 636.

[4] S.H. Joshi and M.K. Thaker, Indian J Chem. 44B (2005) 410.

[5] H.Joshi, P. Upadhayaya, D. Karia and A.J. Baxi, Eur J Med Chem. 38 (2000) 837.

[6] M. Amir, S.A. Javed and H. Kumar, Indian J Chem. 46B (2007) 1014.

[7] A.D. Mishra, Nepal J Sc Tech. 11 (2010) 153.

[8] E.A. Gamal, A.M. Mohamad and A.G. Yehia, Indian J Chem. 39 (2000) 368.

[9] M. Kidwai, P. Mishra and R.K. Bhushan, Polyhedron 18 (1999) 2641.

[10] A.D. Mishra, J Nepal Chem Soc. 25 (2010) 83.

[11] O.M. Pedro, M.P. Jose and I.P. Gean, J Med chem. 1 (2006) 223.

[12] K. Mogilaihi and G.R. Reddy, J Chem Res. 10 (2004) 363.

[13] K. Eger, G. Grieb. and S. Spatting, J Heterocyclic Chem. 27 (1990) 2069.

[14] A.D. Mishra, J Institute Sc Tech. 16 (2010) 135.

[15] S. Gupta and N. Ajmera, Indian J Chem. 48 (2009) 853.

[16] M. Kidwai, A.D. Mishra, Pure Appl Chem. 71 (2001) 147.

[17] M. Kidwai, R. Venkataraman and B. Deve, Green Chem. 3 (2001) 278. 